\title{
Waterborne polar macromolecules act as algal antifoulants in the seaweed Ulva reticulata
}

\author{
Tilmann Harder ${ }^{1,2}$, Sergey Dobretsov ${ }^{1}$, Pei-Yuan Qian ${ }^{1, *}$ \\ ${ }^{1}$ Department of Biology \& Coastal Marine Laboratory, Hong Kong University of Science and Technology, Clear Water Bay, \\ Kowloon, Hong Kong, SAR China \\ ${ }^{2}$ Present address: Institute for Chemistry and Biology of the Marine Environment (ICBM), University of Oldenburg, \\ PO Box 2503, 26111 Oldenburg, Germany
}

\begin{abstract}
Repetitive field observations in Hong Kong waters revealed that the green macroalga Ulva reticulata was conspicuously free of epibiotic macroorganisms. This phenomenon was indicative of some sort of natural antifouling control in a macroalga that has been typified as undefended thus far. In previous studies, we identified the alga itself and a thallus-associated epibiotic Vibrio sp. as sources of waterborne, macromolecular substances with an inhibitory effect on the larval attachment of the polychaete Hydroides elegans. Employing a less artifactual water collection technique under field conditions in this study, we demonstrated that naturally obtained algal exudates evoked a similar inhibitory effect as those obtained artificially under laboratory conditions. In order to interpret the chemical defense system of $U$. reticulata with respect to the production and nature of bioactive metabolites, the allelopathic activity of secondary metabolites obtained from Vibrio sp. and the macroalga was bioassayed and biochemically analyzed in parallel. In addition to H. elegans, bioassays were performed with larvae of the bryozoan Bugula neritina. Different enzyme probes revealed chemical and structural features of the factor inhibitory to larval attachment in both samples, and pointed to large polysaccharide units and sulfate esters as structural parts of the bioactive moiety. Specific susceptibilities of the algal and bacterial samples to proteolytic enzymes indicated that (a) different macromolecular constituents were causative of the inhibitory effect, and (b) that the bioactive moiety in the alga-derived sample comprised a structural connection between carbohydrate(s) and proteinaceous molecular domains. The results indicated an antifouling concept in $U$. reticulata that was presumably driven by at least 2 different waterborne macromolecules, and revealed that highly water soluble macromolecules may play an essential chemical ecological role in a marine system. This exemplifies a distinct concept in comparison to other prominent examples of algal antifoulants, which exclusively comprise comparatively small and non-polar algal metabolites.
\end{abstract}

KEY WORDS: Ulva reticulata - Seaweed - Macroalga · Bacteria · Larval settlement · Epibiosis · Antifouling $\cdot$ Chemical ecology Resale or republication not permitted without written consent of the publisher

\section{INTRODUCTION}

Competition among benthic marine invertebrates for living space on hard substrata is intense, particularly in the photic zone. As a result, complex communities of so-called fouling organisms often densely populate marine surfaces. Biological surfaces contribute to spatial niches in such environments; however, hosting a fouling community may have significant detrimental effects to the basibiont (Dixon et al. 1981, Wahl 1997). In clear con- trast to inanimate marine substrata, the surfaces of many algal and soft-bodied invertebrate species such as seaweeds, sponges and soft corals are virtually free of epibiotic macroorganisms. Since these plants and organisms generally lack mechanical defenses, the observation of reduced macrofouling on their surfaces may be indicative of natural antifouling strategies based on chemical modes of action (McCaffrey \& Endean 1985, Clare 1996).

Regarding potential chemical defense strategies targeting epibiotic macroorganisms, biologically active 
host secondary metabolites may control attachment of planktonic larvae either directly, i.e. by toxic effects and deterrence, or indirectly by modification of the microbial community profile in biofilms on the basibiont (Wahl 1997, Steinberg \& de Nys 2002). Given that qualitative and quantitative features of microbial surface communities modulate the magnitude of larval attachment in many marine invertebrates (Wieczorek \& Todd 1998, Harder et al. 2002, Lau et al. 2002, Lam et al. 2003), the indirect mode of action provides an effective means to control the surface colonization of epibiotic macroorganisms.

The hypothesis of seaweed-derived allelochemicals that deter colonization of algal thalli by epibiota has received particular attention. Macroalgal secondary metabolites with antifouling properties, such as diterpene alcohols (Schmitt et al. 1995), brominated phenolics (Phillips \& Towers 1982) and sesquiterpenoids (de Nys et al. 1998) in brown and red algae, respectively, have been demonstrated to directly affect the colonization of invertebrate larvae by deterrence and/or toxicity. Others, such as halogenated furanones in the red alga Delisea pulchra, interfere with bacterial signaling systems and impair colonization by fouling bacteria through growth inhibition and negative chemotaxis (Steinberg et al. 1997, Maximilien et al. 1998). The commonality of these antifoulants is not only their small molecular size but also, importantly, their unpolar character. These physico-chemical attributes are suggested to be of critical significance for secondary metabolites to function as natural antifoulants in the absence of strong boundary-layer effects (reviewed in Wahl 1989, Steinberg et al. 2002).

Contrary to the well-known modes of allelochemical defense against epibiosis in brown and red algae (Fusetani 1997, Steinberg et al. 2002), comparative studies with green algae are rare (Walters et al. 1996). The present investigation is a follow-up study based on preliminary results obtained with the green macroalga Ulva reticulata. In Hong Kong waters, field observations from 1997 to 2003 revealed U. reticulata thalli to be conspicuously free of epibiotic macroorganisms throughout the peak season of growth between February and June (authors' pers. obs.). However, when the physiological condition of algae deteriorated during late summer due to increasing water temperature, more typical fouling invertebrates such as bryozoans, tubeworms and barnacles were progressively observed on the seaweed. Our recurrent field observation was indicative of some sort of natural antifouling control in $U$. reticulata, which has previously been regarded as an undefended green alga, and initiated a series of studies into the underlying modes of a presumptive defense mechanism.

Firstly, we discovered that waterborne exudates of Ulva reticulata with an estimated molecular size of more than $100 \mathrm{kDa}$ inhibited larval attachment of the serpulid polychaete Hydroides elegans (Harder \& Qian 2000). Secondly, waterborne metabolites of a thallusassociated bacterial isolate from $U$. reticulata were shown to evoke a significant inhibition of larval attachment in $H$. elegans. In analogy to the prior study concerning the alga-derived compound(s) inhibitory to larval attachment, the biological activity of the bacteriaderived products was also caused by macromolecules larger than 100 kDa (Dobretsov \& Qian 2002).

Since the only known group of water-soluble macromolecular alga-derived antifoulants (i.e. phlorotannins, Sieburth \& Conover 1965) is specifically found in brown algae, these preliminary results indicated that in the green alga Ulva reticulata epibiotic macroorganisms were deterred by some hitherto unknown macromolecular constituents in the algal and/or bacterial exudates. In this study, we aimed to purify and chemically classify the bioactive, macromolecular constituents in the crude samples obtained from the algal culture medium and bacteria-conditioned water samples under laboratory conditions, in order to interpret the chemical defense system of $U$. reticulata regarding the production of bioactive metabolites of bacterial host associates. In addition to the larval test organism Hydroides elegans employed in our prior studies, we extended these experiments to the settling stage of another dominant member in subtropical biofouling communities, i.e. the bryozoan Bugula neritina. In order to assess the ecological significance of the algal exudates, the water surrounding tufts of $U$. reticulata was trapped under field conditions and bioassayed with the larval testing system mentioned above.

\section{MATERIALS AND METHODS}

Larval culture and bioassay procedures. Adult broodstocks of the polychaete Hydroides elegans (Haswell) and the bryozoan Bugula neritina (Linnaeus) were collected from piling and floating rafts in Port Shelter Bay, Hong Kong $\left(22^{\circ} 19^{\prime} \mathrm{N}, 114^{\circ} 16^{\prime} \mathrm{W}\right)$. Batch cultures of polychaete larvae were reared for $5 \mathrm{~d}$ to competent stage according to Harder \& Qian (1999). Bryozoan larvae were obtained according to Bryan et al. (1997), and newly hatched larvae were included in bioassays. Stillwater laboratory bioassays were performed with 5 replicates in sterile polystyrene petri dishes (\#1006, Falcon) containing 20 larvae, and the sample under investigation in $4 \mathrm{ml}$ of sterile-filtered $(0.22 \mu \mathrm{m})$ seawater (FSW). Larval attachment assays were run at $28^{\circ} \mathrm{C}$ under continuous illumination for $1 \mathrm{~h}$. After this time, attached juveniles were enumerated and attachment was expressed as a percentage. In some treatments, the bacterial abundance in experimental dishes 
was determined after the bioassays. The attached bacteria were visualized with the DNA-binding fluorochrome 4,6-diamidino-2-phenylindole (DAPI, Fluka Chemie AG) at $0.5 \mu \mathrm{g} \mathrm{ml}^{-1}$. The formalin-fixed (4\% in FSW) petri dishes $(n=3)$ were rinsed with distilled water and stained with DAPI for $5 \mathrm{~min}$. Stained dishes were wet-mounted on a fluorescence microscope (Zeiss Axiophot) and bacterial cells in 5 randomly chosen fields of view of known size were recorded at $1250 \times$ magnification $\left(\lambda_{\mathrm{Ex}}=359 \mathrm{~nm}, \lambda_{\mathrm{Em}}=441 \mathrm{~nm}\right)$.

In all bioassays, FSW served as the control. In bioassays with Hydroides elegans, the phosphodiesterase inhibitor 3-isobutyl-1-methylxanthine (IBMX) at $10^{-4} \mathrm{M}$ in FSW was included as an artificial stimulant of larval attachment (Pechenik \& Qian 1998).

Preparation of Ulva-conditioned seawater (laboratory/field). The macroalga Ulva reticulata (Forsskal) was collected during the peak period of growth underneath rafts in Port Shelter, Hong Kong $\left(22^{\circ} 19^{\prime} \mathrm{N}\right.$, $114^{\circ} 16^{\prime} \mathrm{W}$ ) in April 2002 by carefully loosening the holdfasts without damaging algal blades. The algae were immediately weighed (wet weight) and $500 \mathrm{~g}$ were floated in acid-cleaned 21 glass beakers containing $1 \mathrm{l}$ of seawater from the same location. The beakers were aerated and incubated at $25^{\circ} \mathrm{C}$ on a $15: 9 \mathrm{~h}$ light: dark photoperiod with overhead fluorescent lights (irradiance $0.3 \times 10^{16}$ quanta $\mathrm{s}^{-1} \mathrm{~cm}^{-1}$ ). Natural seawater from the collection site was treated similarly and served as a control. After $24 \mathrm{~h}$ of incubation, the alga-conditioned seawater (CSW) and the control (NSW-control) were filtered through $0.22 \mu \mathrm{m}$ nylon membranes followed by ultrafiltration through membranes with $100 \mathrm{kDa}$ cut-off size (Millipore). Retained macrosolutes were dissolved in double-distilled water, freeze-dried and weighed, yielding known amounts of the residues with $>100 \mathrm{kDa}$ cut-off size. For larval attachment assays, the $>100 \mathrm{kDa}$ size fraction of UCW was reconstituted in FSW at original concentration $(1 \times)$.

Waterborne exudates of Ulva reticulata were obtained less artifactually at the collection site according to a method adopted from Jennings \& Steinberg (1994). Briefly, tufts of algal blades were encased in transparent plastic bags. The ratio of plant wet weight to water volume in the plastic bag was similar to the laboratory conditions chosen above. After a conditioning time of $1 \mathrm{~h}$, the water sample was subject to the filtration sequence above.

Development of bacterial films and preparation of Vibrio film-conditioned water: The epibiotic Vibrio sp. isolated from thalli of Ulva reticulata was deposited at the Marine Bacteria Culture Collection at the Hong Kong University of Science and Technology (Strain ID: UST991130-070). The bacterium was inoculated into sterile culture broth $(0.5 \% \mathrm{w} / \mathrm{v}$ peptone, $0.3 \% \mathrm{w} / \mathrm{v}$ yeast extract in FSW) and grown at $30^{\circ} \mathrm{C}$ for $48 \mathrm{~h}$ to sta- tionary phase. Suspended bacteria were harvested by centrifugation and diluted in autoclaved FSW to an optical density of 0.1 at a wavelength of $610 \mathrm{~nm}$. Polystyrene petri dishes were filled with $4 \mathrm{ml}$ of bacterial suspension and incubated for $3 \mathrm{~h}$ at $22^{\circ} \mathrm{C}$ for the attachment of bacteria, after which dishes were diprinsed several times in autoclaved FSW to remove unattached cells. Besides the dishes for larval attachment assays, 3 dishes were treated similarly for subsequent enumeration of bacteria on the dish surface. Filmed dishes were filled with $4 \mathrm{ml}$ of FSW and incubated for $1 \mathrm{~h}$ at $22^{\circ} \mathrm{C}$ to obtain waterborne bacterial products. The Vibrio film-conditioned water (in the following abbreviated as VCW) was sterile filtered (0.22 $\mu \mathrm{m}$ nylon membranes) and subsequently passed through $100 \mathrm{kDa}$ molecular cut-off membranes. The VCW was transferred into new dishes whilst the bacteria-filmed set of dishes was thoroughly dip-rinsed and refilled with $4 \mathrm{ml}$ of FSW. Both experimental sets, i.e. dishes containing the $>100 \mathrm{kDa}$ size fraction of VCW and monospecific Vibrio sp. films, were subject to larval attachment assays.

Enzyme treatments of Vibrio film- and Ulva-conditioned water samples: Different proteolytic and glycolytic enzyme probes were used in digestion experiments of Vibrio film- and Ulva-conditioned water samples (VCW and UCW) to reveal structural determinants of biological activity. Concentrated stock solutions of the following enzymes were prepared in $10 \mathrm{mM}$ Tris- $\mathrm{HCl}$ (pH: 7) in 50\% glycerol and diluted with conditioned water samples (enzyme treatment) or FSW (enzyme blank) to the following working concentrations: trypsin (from bovine pancreas) at $0.01 \mathrm{mg}$ $\mathrm{ml}^{-1}$, papain at $0.2 \mathrm{mg} \mathrm{ml}^{-1}, \beta$-glucuronidase (from bovine liver) at $0.01 \mathrm{mg} \mathrm{ml}^{-1}$, sulfatase (from Patella vulgata) at $0.5 \mathrm{mg} \mathrm{ml}^{-1}$, and $\alpha$-amylase (from Bacillus sp.) at $0.01 \mathrm{mg} \mathrm{ml}^{-1}$ (all enzymes were obtained from Sigma). Enzyme incubations were carried out at $25^{\circ} \mathrm{C}$ for $3 \mathrm{~h}$ and samples were used without further purification in larval attachment assays with Bugula neritina. After the assay, non-attached larvae were transferred into FSW to monitor their ability to attach after exposure to enzymes.

Bioassay-guided fractionation of Vibrio film- and Ulva-conditioned water: Aliquots of Vibrio film- (VCW) and Ulva-conditioned water (UCW) obtained under laboratory conditions were concentrated $(1000 \times)$ by ultrafiltration $(100 \mathrm{kDa})$ and fractionated by sizeexclusion chromatography (SEC) on Sephacryl S-400 HR (Pharmacia; $1.6 \times 30 \mathrm{~cm}$ ) with isochratic elution of $0.1 \mathrm{M}$ phosphate buffer $(\mathrm{pH}$ 8). The SEC-fractions were desalted by ultrafiltration and reconstituted at original concentration for larval bioassays with Hydroides elegans or freeze-dried for subsequent chemical analysis. 
Glycosyl composition analysis: Freeze-dried biologically active SEC-fractions were analyzed for glycosyl composition at the Complex Carbohydrate Research Center (CCRC) at the University of Georgia, USA. The VCW-sample was analyzed by alditol acetate derivatization of monosaccharides. Briefly, the sample was hydrolyzed with $2 \mathrm{M}$ trifluoroacetic acid (TFA) for $2 \mathrm{~h}$ in a sealed tube at $121^{\circ} \mathrm{C}$, subsequently reduced with sodiumborodeuteride, and acetylated with an equimolar mixture of acetic anhydride and TFA. The resulting alditol acetates were analyzed on a Hewlett Packard 5890 gas chromatograph interfaced to a 5970 mass selective detector in electron impact ionization mode. Separation was performed on a bonded-phase fused silica capillary column (All Tech EC-1, $30 \mathrm{~m} \times 0.25 \mathrm{~mm}$ ). The UCW sample was analyzed by per-O-trimethylsilyl (TMS) derivatization of monosaccharides. Briefly, methyl glycosides were prepared by acidic methanolysis of the sample in $1 \mathrm{M}$ methanolic $\mathrm{HCl}$ for $18 \mathrm{~h}$ at $80^{\circ} \mathrm{C}$, followed by $\mathrm{N}$-acetylation with methanolic pyridine and acetic anhydride in methanol. The released sugars were per-O-trimethylsilylated by treatment with Tri-Sil (Pierce Biotechnology) for $30 \mathrm{~min}$ at $80^{\circ} \mathrm{C}$ and TMS-methyl glycosides were analyzed on the GCMS system mentioned above. Twenty $\mu \mathrm{g}$ of inositol was added to both samples prior to derivatization as an internal standard.

Statistical analysis. The percentage values of larval attachment in response to experimental treatments were arcsine-transformed. To improve the arcsinetransformation, replicates with no attachment were given the value of $(4 \times n)^{-1}(n=$ number of larvae in a single replicate) (Zar 1996). The homogeneity and normality of data sets was analyzed with Levene's and Shapiro-Wilk's $W$-test, respectively, at a confidence level of $95 \%$. Data that violated the normality assumption were analyzed non-parametrically by ranktransformation followed by 1-way ANOVA, Tukey's multiple comparison or multiple pair-wise comparison versus a negative control (Dunnett's test) at $95 \%$ confidence level (Conover \& Iman 1981). Statistical calculations were performed with the SPSS software package, Version 11.

\section{RESULTS}

\section{Effect of Ulva-conditioned water in larval bioassays}

Larval attachment was significantly inhibited in the presence of crude Ulva-conditioned water (UCW) and the $>100 \mathrm{kDa}$ size-fraction of UCW (Hydroides elegans, $\mathrm{p}<0.001, F=18.21$, 1 -way ANOVA; Bugula neritina, $\mathrm{p}<0.001, F=17.03$, 1-way ANOVA) after $1 \mathrm{~h}$ (Fig. 1A,C). The high molecular weight fraction of
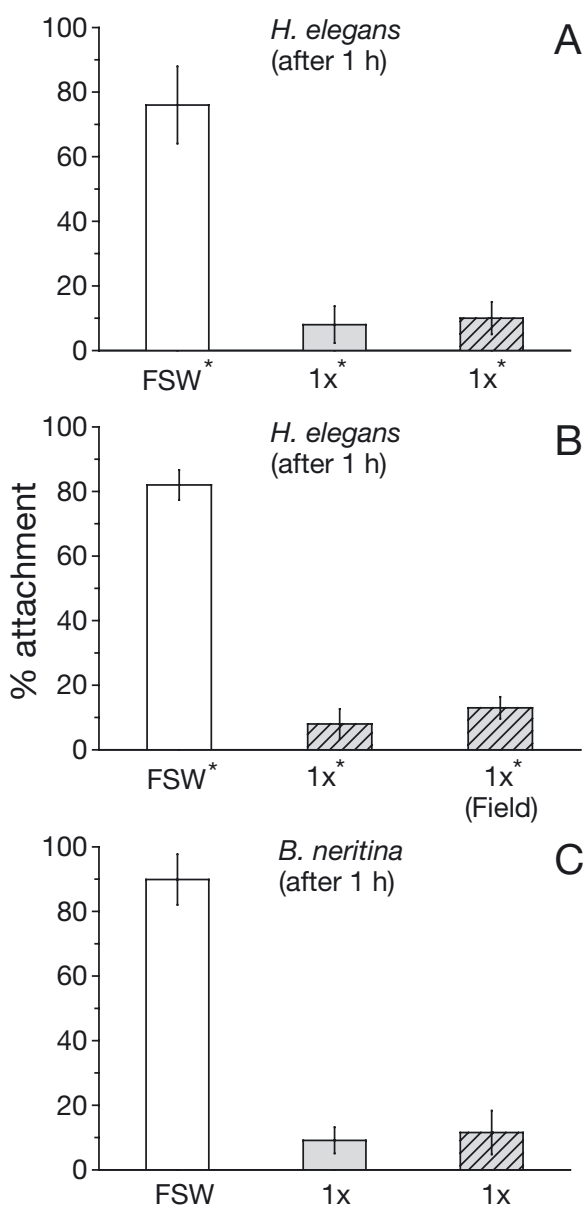

Fig. 1. Effect of Ulva-conditioned water (shaded grey) and its $>100 \mathrm{kDa}$ size fraction (hatched) after $1 \mathrm{~h}$, on larval attachment of Hydroides elegans (A,B) and Bugula neritina (C). Samples were assayed at original concentration $(1 \times)$ together with a control of $0.22 \mu \mathrm{m}$-filtered seawater (FSW, white). If not otherwise indicated as 'Field', the samples were obtained under laboratory conditions. Experimental treatments in the presence of $10^{-4} \mathrm{M}$ phosphodiesterase inhibitor 3-isobutyl1-methylxanthine (IBMX) are asterisked. Percentage data of larval attachment are means $\pm \mathrm{SD}$ of 5 replicates

UCW sample obtained under field conditions (UCW-F) evoked a similar inhibitory effect on larval settlement of $H$. elegans as the corresponding laboratorygenerated sample $(p=0.40, F=1.6,1$-way ANOVA; Fig. 1B).

\section{Effect of attached Vibrio sp. and Vibrio film-conditioned water on larval attachment}

The bacterial abundance in monospecific Vibrio sp. films (VF) that served for the preparation of VCW ranged between 4200 and 5700 cells $\mathrm{mm}^{-2}$ (Fig. 2B). The larval response to VF and the $>100 \mathrm{kDa}$ size fraction of VCW was species-specific. In assays with 
Hydroides elegans, the percentage attachment in the presence of VF and VCW was significantly lower ( $\mathrm{p}<0.05$, Tukey's test) than in the FCW-control after $1 \mathrm{~h}$ (Fig. 2A; $\mathrm{p}<0.001, F=9.54,1$-way ANOVA). In assays with Bugula neritina, a significant inhibitory effect was only observed in VCW ( $p<0.05$, Tukey's test) but not in VF (Fig. 2A; $p<0.005, F=9.22$, 1-way ANOVA). The bacterial abundance in test dishes after the bioassay was low, and ranged between 200 and 550 cells $\mathrm{mm}^{-2}$ (Fig. 2B).

\section{Effect of enzyme treatments of Ulva- and Vibrio-film conditioned water on larval attachment}

In comparison to the FSW-control there was no effect of enzyme blanks on larval attachment of Bugula neritina after $1 \mathrm{~h}(\mathrm{p}=0.99, F=0.09,1$-way ANOVA).
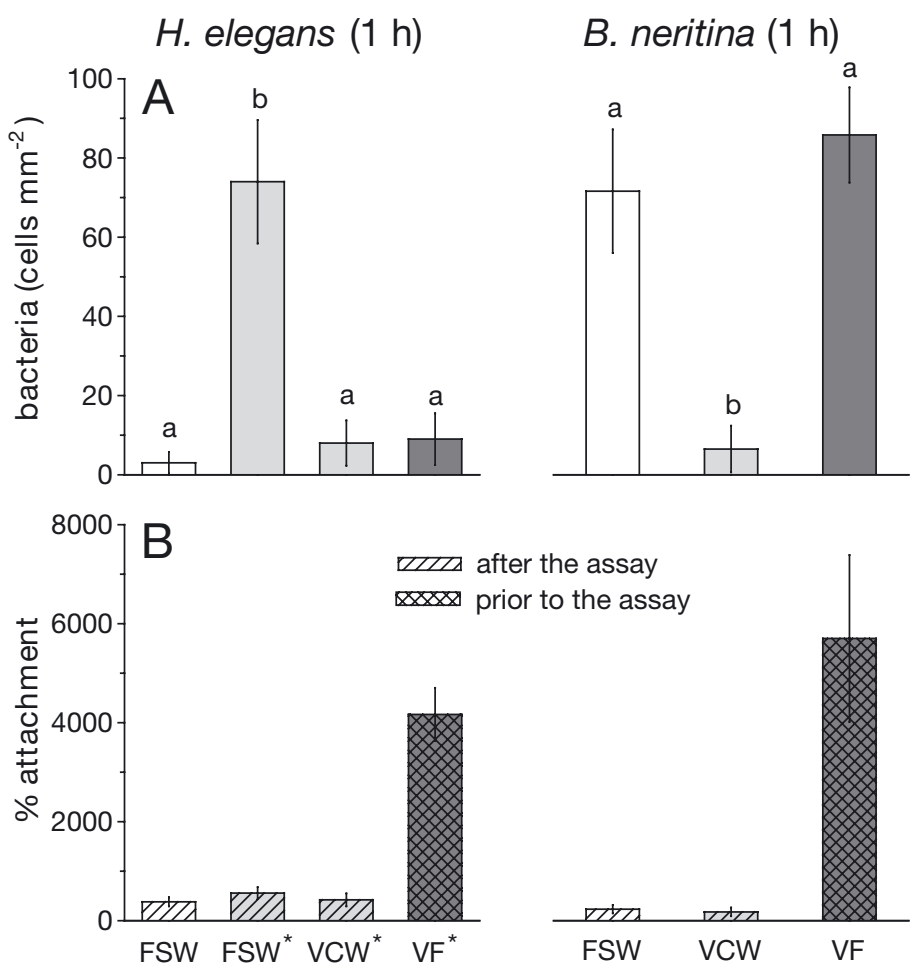

Fig. 2. (A) Effect of monospecific Vibrio sp. films (VF, shaded dark grey) and the $>100 \mathrm{kDa}$ size fraction of Vibrio filmconditioned water (VCW, shaded light grey) on larval attachment of Hydroides elegans and Bugula neritina after $1 \mathrm{~h}$, in comparison to a control of $0.22 \mu \mathrm{m}$-filtered seawater (FSW, white). Experimental treatments in the presence of $10^{-4} \mathrm{M}$ phosphodiesterase inhibitor 3-isobutyl-1-methylxanthine (IBMX) are asterisked. Percentage data of larval attachment are means \pm SD of 5 replicates. SDs among treatments are indicated by different letters above bars ( $\alpha=0.05$, Tukey's test). (B) Abundance of bacterial cells in VF prior to the bioassay and test dishes that contained VCW and FSW after termination of the bioassay (hatched)
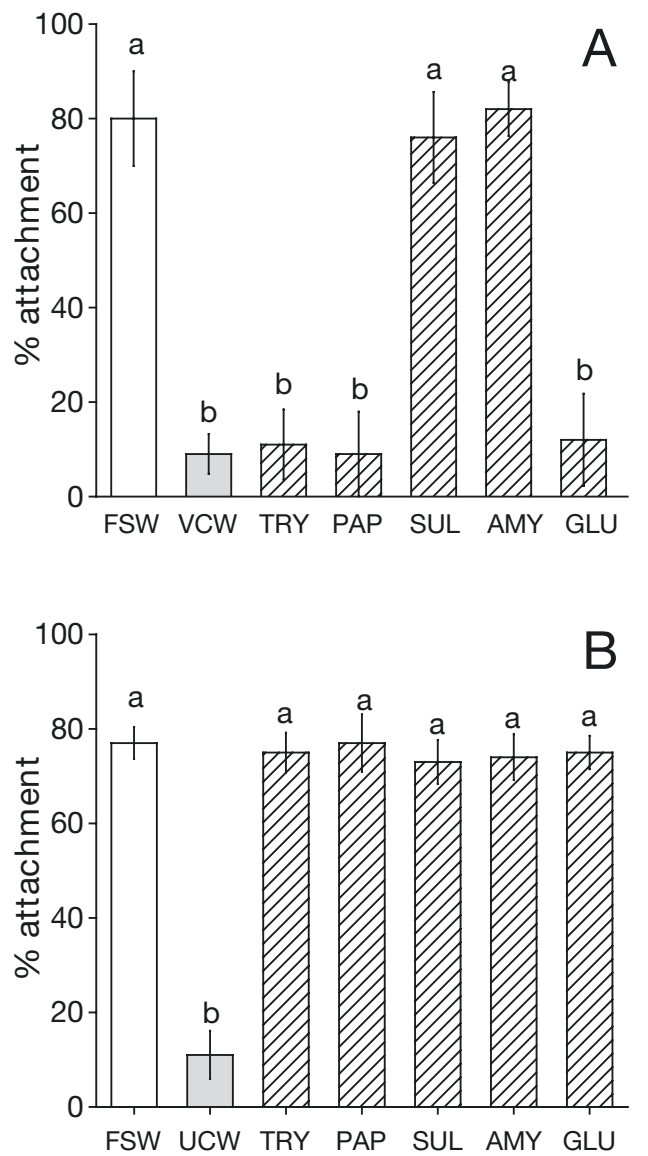

Fig. 3. Effect of enzyme treatments (hatched) of Vibrio-film(VCW; A) and Ulva-conditioned water (UCW; B) on larval attachment of Bugula neritina in comparison to positive control of $0.22 \mu \mathrm{m}$-filtered seawater (FSW, white) and negative control of VCW and UCW, respectively (shaded grey). Enzymes under investigation were trypsin (TRY), papain (PAP), sulfatase (SUL), $\alpha$-amylase (AMY) and $\beta$-glucuronidase (GLU). Percentage data of larval attachment are means \pm SD of 5 replicates. Significant differences among treatments are indicated by letters above bars $(\alpha=0.05$, Tukey's test)

After incubation of Ulva- (UCW) and Vibrio film-conditioned water $(\mathrm{VCW})$ with different enzyme probes, larval attachment differed significantly among treatments (Fig. 3; $\mathrm{p}<0.001, F=13.83,1$-way ANOVA). The percentage attachment to VCW treated with sulfatase (SUL) and $\alpha$-amylase (AMY) was significantly higher than in the VCW-control $(p<0.001$, Tukey's test). The percentage attachment to VCW treated with trypsin (TRY), papain (PAP), and $\beta$-glucuronidase (GLU) was the same as in the VCW-control. In contrast to the enzyme results obtained with $\mathrm{VCW}$, all the enzyme treatments of UCW resulted in high percentages of larval attachment, statistically different from the UCW-control $(\mathrm{p}<0.001, F=23.385,1$-way ANOVA). Non-attached larvae readily metamorphosed after transferal into dishes with FSW. 


\section{Bioassay-guided fractionation of Vibrio film- and Ulva-conditioned water}

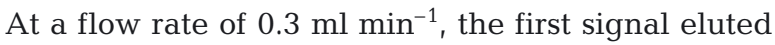
right after the column void volume of $5 \mathrm{ml}$. The sizeexclusion chromatogram (SEC) of concentrated VCW revealed at least 3 distinguishable bands. The eluate was sampled in 7 fractions (VCW-1 to 7 ) in the retention window bracketed by 15 and $190 \mathrm{~min}$. The fractionation profile is indicated in Fig. 4A. The factor inhibitory to larval attachment of Hydroides elegans eluted with VCW-2, 3, 4 and 5 in a concentrationdependent fashion, indicating a chromatographic tailing effect of the biologically active sample constituents within the retention window bracketed by 65 to 120 min (Fig. 4A; p < 0.001, Dunnett's multiple pairwise comparison against the FSW-control, $\alpha=0.05$ ). The SEC of concentrated UCW revealed at least 6 distinguishable bands. The eluate was sampled in 5 frac- tions (UCW-1 to 5) in the retention window bracketed by 15 and $180 \mathrm{~min}$. The fractionation profile is indicated in Fig. 4B. The factor inhibitory to larval attachment of $H$. elegans eluted with Fractions 2 and 3 (Fig. 4B; $\mathrm{p}<0.001$, Dunnett's multiple pairwise comparison against the FSW-control, $\alpha=0.05$ ).

\section{Carbohydrate monomer composition of bioactive chromatographic fractions of Vibrio film- and Ulva-conditioned water samples}

The biologically active SEC-fractions UCW-2 and VCW-2 were subject to compositional carbohydrate analysis. Monosaccharides were identified by their retention times in comparison to standards, and authenticated by their mass spectra. The monomer compositions of both samples are given in Table 1.
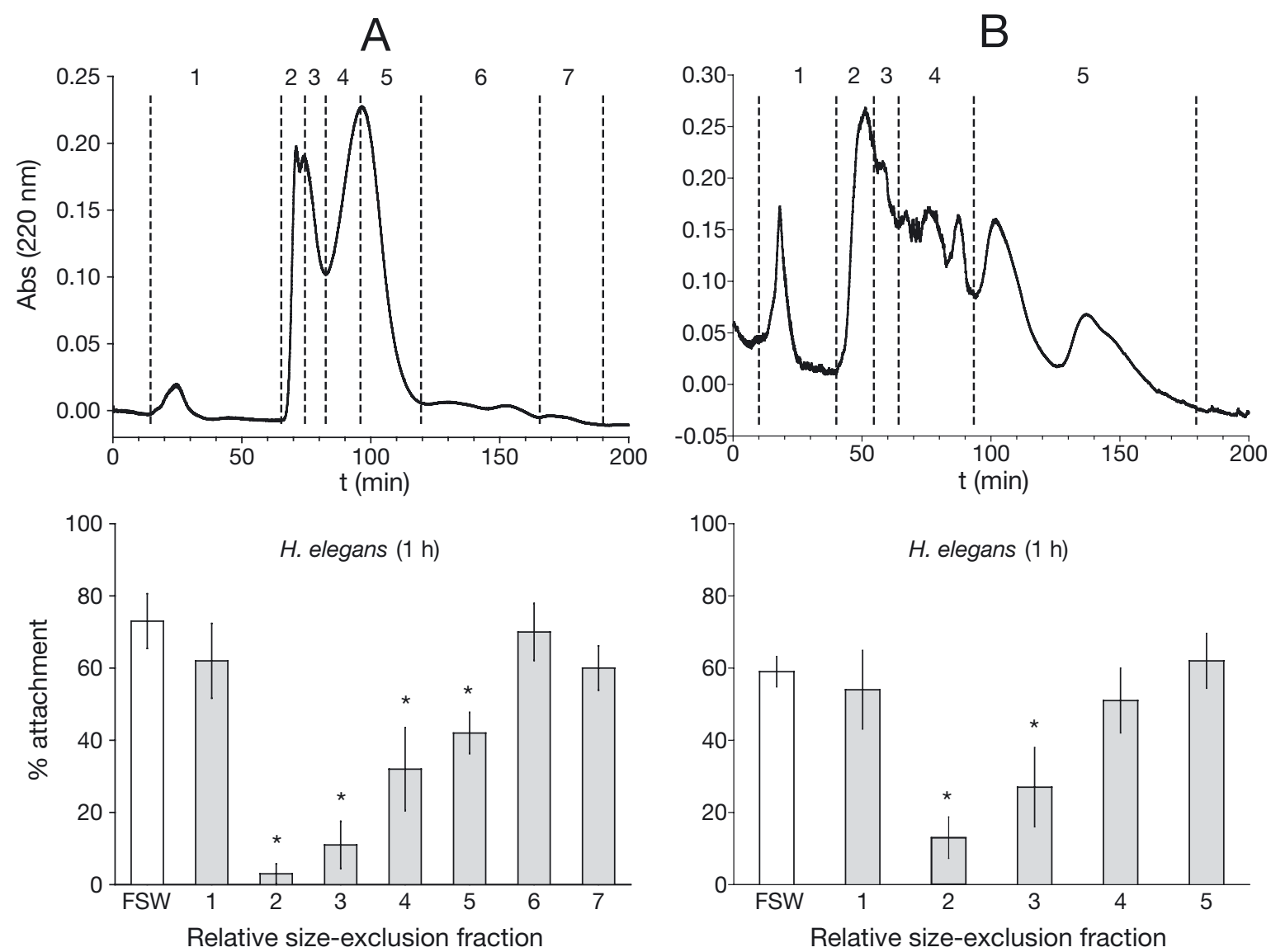

Fig. 4. Bioassay-guided size-exclusion fractionation of (A) Vibrio film- and (B) Ulva-conditioned water and the effect of individual size-fractions on larval attachment of Hydroides elegans (after $1 \mathrm{~h}$ ) incubation in the presence of $10^{-4} \mathrm{M}$ phosphodiesterase inhibitor 3-isobutyl-1-methylxanthine (IBMX; shaded grey) in comparison to a control of $0.22 \mu \mathrm{m}$-filtered seawater (FSW, white). Chromatographic parameters: Sephacryl S-400 HR $(1.6 \times 30 \mathrm{~cm}) ; 200 \mu$ injection; isochratic elution with $0.1 \mathrm{M}$ phosphate buffer $(\mathrm{pH} 8)$ at $0.3 \mathrm{ml} \mathrm{min}{ }^{-1}$. Vertical dotted lines indicate the fractionation profile. Data plotted are means \pm SD of 5 replicates. Significant statistical differences in comparison to the control are asterisked (Dunnett's test) 
Table 1. Carbohydrate monomer composition of bioactive chromatographic fractions obtained from Vibrio sp. film- and Ulva-conditioned water samples by size exclusion chromatography

\begin{tabular}{|lcc|}
\hline Monomers (mole \%) & Vibrio Fraction 2 & Ulva Fraction 2 \\
\hline Fucose & - & 7.8 \\
Galactose & 11.8 & 31.6 \\
Glucose & 24.2 & 14.6 \\
Glucuronic acid & - & 3.0 \\
Heptose (unidentified) & 27.8 & - \\
Mannose & - & 5.5 \\
Methylated sugars & - & 2.9 \\
N-acetyl galactosamine & 6.9 & - \\
N-acetyl glucosamine & 29.3 & 5.1 \\
Rhamnose & - & 17.4 \\
Uronic acid (unidentified) & - & 2.2 \\
Xylose & - & 9.9 \\
\hline
\end{tabular}

\section{DISCUSSION}

In addition to our previous results obtained with the polychaete Hydroides elegans (Harder \& Qian 2000), the allelochemical effect of macromolecular, waterborne antifoulants of Ulva reticulata was demonstrated with the bryozoan Bugula neritina, another dominant member of epibiotic communities (Fig. 1). Employing a non-, or by far less, artifactual water collection technique under field conditions, we showed that natural algal exudates evoked a similar inhibitory effect on larval settlement as artificially obtained algal metabolic substances under laboratory conditions (Fig. 1C). These results validated the laboratory procedures and the experimental results obtained with crude samples of algal metabolites generated under laboratory conditions.

In order to interpret the chemical defense system of Ulva reticulata with respect to the production of bioactive metabolites of bacterium-host associates, the allelopathic activity of secondary metabolites obtained from a thallus-associated epibiotic Vibrio sp. was investigated in detail. It is important to note that the generation of waterborne bacterial metabolites in this study differed from the previously employed technique. Contrary to the enrichment of bacterial metabolites in cell suspensions of high concentration over a prolonged period of time $(12 \mathrm{~h}$, Dobretsov \& Qian 2002), the exposure of thin monospecific Vibrio film to seawater over $1 \mathrm{~h}$ was comparatively short in this study. Monospecific Vibrio films were prepared at approximately 5000 cells $\mathrm{mm}^{-2}$, which is, in our experience, the lowest reproducible adjustment of bacterial cell densities on artificial substrata. Although we did not know the natural abundance of the epibiotic Vibrio sp. on the thalli of $U$. reticulata at this stage, this approach was considered to be ecologically more appropriate due to the brief conditioning period of seawater with a benthic source of Vibrio sp. at approximately $50 \%$ of the total abundance of epibiotic bacteria on thalli of $U$. reticulata (Dobretsov \& Qian 2002). Under these experimental conditions, larval attachment was significantly reduced in the presence of Vibriofilm conditioned water (Fig. 2A). The contamination of test dishes by bacteria during these assays was negligibly low (Fig. 2B), thus metabolites originating from Vibrio films were considered to be causative of the inhibitory effect on larval attachment. While bryozoan larval attachment was unaffected in the presence of Vibrio films, polychaete larvae were similarly inhibited as in the case of Vibrio-film conditioned water. Overall, our results indicated that other than waterborne bacterial metabolites, factors associated with the bacterial film surface might have superseded inhibitory effects on larval attachment in a species-specific manner. By demonstrating that larvae from experimental treatments readily attached after transferring them into dishes with new seawater (data not shown), the inhibitory effect of the algal and bacterial waterborne products on larval attachment was considered to be direct, reversible and non-toxic.

Preliminary biochemical analyses of crude UCW and VCW indicated the presence of carbohydrates and in the case of VCW also of proteins (data not shown). Therefore, different glycolytic and proteolytic enzymes were used as probes for a structural correlation of macromolecular constituents in UCW and VCW with their potential biological activity. The enzyme probes revealed some chemical and structural features of the factor inhibitory to larval attachment. The effective inactivation of both crude samples after incubation with $\alpha$-amylase, $\beta$-glucuronidase and sulfatase, together with a clear correlation of biological activity with macromolecular components larger than $100 \mathrm{kDa}$, pointed to large polysaccharide units in the bioactive sample components (Fig. 3). The effective elimination of the biological activity by sulfatase indicated the presence of organic sulfate esters as a structural part of the bioactive moiety. While the activity of VCW was indifferent to the proteolytic enzyme treatment, the activity of UCW was effectively eliminated by trypsin and papain, indicating that the bioactive moiety comprised a structural connection between carbohydrate(s) and proteinaceous molecular domains. The observation that non-attached larvae readily metamorphosed in FSW after their exposure to enzymes proved that the capacity of larval attachment was not affected by enzyme probes, and furthermore verified that the inhibitory factor to larval settlement in UCW and VCW was indeed the substrate in the digestion experiments. The structural differences of the inhibitory factor to 
larval attachment revealed by the treatment of the crude samples with glycolytic enzymes were in accordance with the identification of the respective carbohydrate monomers, as revealed by compositional carbohydrate analysis in purified UCW and VCW (Table 1).

Owing to the elimination of the antifouling effect by glycolytic enzymes and the large molecular size of the antifoulants in UCW and VCW, the inhibitory factor to larval attachment in both samples was interpreted to be structurally associated with a polysaccharide unit. However, due to the uncertainty whether bioactive fractions obtained by size exclusion chromatography were chromatographically pure, it was not clear whether the identified carbohydrate monomer profiles (Table 1) accurately reflected the qualitative and quantitative sugar composition of the bioactive macromolecules in UCW and VCW. The different susceptibilities of UCW and VCW to proteolytic enzymes indicated that different macromolecular constituents were causative of the inhibitory effect to larval attachment. In summary, these results indicated an antifouling concept in Ulva reticulata that was presumably driven by at least 2 different waterborne macromolecules, one of which originated from an epibiotic bacterium. Because of the non-axenic generation procedure for waterborne algal products, the putative origin (i.e. algal or bacterial) of the other antifoulant could not be faithfully distinguished.

The ability of host-associated microorganisms to render living surfaces unfavorable to subsequent microbial and larval colonizers has previously been suggested in the context of fungal protection of crustacean larvae (Gil-Turness et al. 1989) and the prevention of larval attachment and bacterial colonization of tunicates (Holmström et al. 1992), corals (Harder et al. 2003) and seaweeds (Boyd et al. 1999, Burgess et al. 2003). However, the interpretation of a complementary ecological role in putative antifouling mechanisms by epibiotic bacteria comprises a speculative element, as long as there is uncertainty about their symbiotic relationship with the host and their actual abundance on the host. In this respect, the present study was no exception, and therefore, the metabolite fraction in Ulva-conditioned water was considered to be specific to the alga regardless of potentially different sources.

Importantly, this study revealed that highly watersoluble macromolecules may play an essential chemical ecological role in a marine system, thus exemplifying a distinct concept in comparison to prominent examples of other algal antifoulants (e.g. Phillips \& Towers 1982, Schmitt et al. 1995, Steinberg et al. 1997, de Nys et al. 1998). So far, the established hypothesis of a correlation between secondary metabolites and their surface-associated effects against epibiota was physico-chemically explained with bioinformative molecules of low polarity, and hence low solubility in water (Clare 1996, Steinberg et al. 1998). This concept was considered to be an important determinant of the utility of metabolites as chemical signals that are beneficial to their source of exudation, because in the absence of boundary layer effects, polar exudates should readily diffuse from the source and result in steep chemical gradients of chemical cues. In order to chemically deter surface colonization of pelagic biota by polar and water-soluble molecules, these compounds should be exuded in large enough quantities to maintain an effective concentration at or in close proximity to the surface.

We speculate that the principal requirements for an effective concept of polar, water-soluble compounds at critical boundary layer threshold concentration may be fulfilled in the biological system under investigation, for the following reason. Larvae of Hydroides elegans and Bugula neritina generally exhibit extensive surface exploration of marine substrata prior to their irreversible attachment and metamorphosis. During this exploratory phase, any chemical inhibitory effects on larval attachment should be mediated through effective threshold concentrations of bioactive macromolecules in the surface boundary layer on the thalli of Ulva reticulata. Due to the high binding affinity of exopolymeric compounds in bacterial films to many water-soluble macromolecules, such as proteins, polysaccharides and glycoproteins (Decho 1990, 2000), we hypothesize that despite their otherwise ecologically unfavorable solubility and diffusion characteristics, polar macromolecules may be concentrated in the boundary layer and function as potent allelopathic mediators under these circumstances.

Acknowledgements. We thank S. C. K. Lau and 3 anonymous reviewers for helpful comments on the manuscript. This work was supported in part by the Department of Energy-funded (DE-FG02-93ER-200097) Center for Plant and Microbial Complex Carbohydrates and by RGC grants HKUST 6119/01M, CAG00/01.SC01 and HKUST6100/02M to P.Y.Q.

\section{LITERATURE CITED}

Boyd KG, Adams DR, Burgess JG (1999) Antibacterial and repellent activities of marine bacteria associated with algal surfaces. Biofouling 14:227-236

Bryan PJ, Rittschof D, Qian PY (1997) Settlement inhibition of bryozoan larvae by bacterial films and aqueous leachates. Bull Mar Sci 61:849-857

Burgess JG, Boyd KG, Armstrong E, Jiang Z and 6 others (2003) The development of a marine natural productbased antifouling paint. Biofouling 19(S):197-205

Clare AS (1996) Marine natural product antifoulants: status and potential. Biofouling 9:211-229

Conover WJ, Iman L (1981) Rank transformations as a bridge 
between parametric and nonparametric statistics. Am Stat 35:124-129

de Nys R, Dworjanyn SA, Steinberg PD (1998) A new method for determining surface concentrations of marine products on seaweeds. Mar Ecol Prog Ser 162:79-87

Decho AW (1990) Microbial exopolymer secretions in ocean environments: their role(s) in food webs and marine processes. Oceanogr Mar Biol Annu Rev 28:73-153

Decho AW (2000) Microbial biofilms in intertidal systems: an overview. Cont Shelf Res 20:1257-1273

Dixon JS, Schroeter M, Kastandiek J (1981) Effects of the encrusting bryozoan, Membranipora membranacea, on the loss of blades and fronds of the giant kelp Macrocystis pyrifera. J Phycol 17:41-345

Dobretsov S, Qian PY (2002) Effect of bacteria associated with the green alga Ulva reticulata on marine micro- and macrofouling. Biofouling 18:217-228

Fusetani N (1997) Marine natural products influencing larval settlement and metamorphosis of benthic invertebrates. Curr Org Chem 1:127-152

Gil-Turnes MS, Hay ME, Fenical W (1989) Symbiotic marine bacteria chemically defend crustacean embryos from a pathogenic fungus. Science 246:116-117

Harder T, Qian PY (1999) Induction of larval attachment and metamorphosis in the serpulid polychaete Hydroides elegans by dissolved free amino acids: isolation and identification. Mar Ecol Prog Ser 179:259-271

Harder T, Qian PY (2000) Waterborne compounds from the green seaweed Ulva reticulata as inhibitive cues for larval attachment and metamorphosis in the polychaete Hydroides elegans. Biofouling 16:205-214

Harder T, Lam C, Qian PY (2002) Induction of larval settlement of the polychaete Hydroides elegans (Haswell) by marine biofilms: an investigation of monospecific diatom films as settlement cues. Mar Ecol Prog Ser 229:105-112

Harder T, Lau SCK, Dobretsov S, Fang TK, Qian PY (2003) A distinctive epibiotic bacterial community on the soft coral Dendronephthya sp. and antibacterial activity of coral tissue extracts suggest a chemical mechanism against bacterial epibiosis. FEMS Microbiol Ecol 43:337-347

Holmström C, Rittschof D, Kjelleberg S (1992) Inhibition of settlement by larvae of Balanus amphitrite and Cliona intestinalis by surface colonizing marine bacterium. Appl Env Microb 58:2111-2115

Jennings JG, Steinberg PD (1994) In situ exudation of phlorotannins by the sublittoral kelp Ecklonia radiata. Mar Biol 121:349-354

Lam C, Harder T, Qian PY (2003) Induction of larval settlement in the polychaete Hydroides elegans by surface-

Editorial responsibility: Otto Kinne (Editor),

Oldendorf/Luhe, Germany associated settlement cues of marine benthic diatoms. Mar Ecol Prog Ser 263:83-92

Lau SCK, Mak KKW, Chen F, Qian PY (2002) Bioactivity of bacterial strains isolated from marine biofilms in Hong Kong waters for the induction of larval settlement in the marine polychaete Hydroides elegans (Haswell). Mar Ecol Prog Ser 226:301-310

Maximilien R, de Nys R, Holmström C, Gram L, Givskov M, Crass K, Kjelleberg S, Steinberg P (1998) Chemical mediation of bacterial surface colonization by secondary metabolites from the red alga Delisea pulchra. Aquat Microb Ecol 15:233-246

McCaffrey EJ, Endean R (1985) Antimicrobial activity of tropical and subtropical sponges. Mar Biol 89:1-8

Pechenik JA, Qian PY (1998) Onset and maintenance of metamorphic competence in the marine polychaete Hydroides elegans (Haswell) in response to 3 chemical cues. J Exp Mar Biol Ecol 226:51-74

Phillips DW, Towers GHN (1982) Chemical ecology of red algal bromophenols. I. Temporal, interpopulational and withinthallus measurements of lanosol levels in Rhodomela larix (Turner) C. Agardh. J Exp Mar Biol Ecol 58:285-293

Schmitt T, Hay M, Lindquist N (1995) Constraints on chemically-mediated coevolution: Multiple functions for seaweed secondary metabolites. Ecology 76:107-123

Sieburth J, Conover JT (1965) Sargassum tannin, an antibiotic which retards fouling. Nature 208:52-53

Steinberg PD, de Nys R (2002) Chemical mediation of colonization of seaweed surfaces. J Phycol 38:621-629

Steinberg PD, Schneider R, Kjelleberg S (1997) Chemical defenses of seaweeds against microbial colonization. Biodegradation 8:211-220

Steinberg P, de Nys R, Kjelleberg S (1998) Chemical cues for surface colonization. J Chem Ecol 28:1935-1951

Steinberg PD, de Nys R, Kjelleberg S (2002) Chemical cues for surface colonization. J Chem Ecol 28:1935-1951

Wahl M (1989) Marine epibiosis. I. Fouling and antifouling: some basic aspects. Mar Ecol Prog Ser 58:175-189

Wahl M (1997) Living attached: aufwuchs, fouling, epibiosis. In: Nagabhushanam $\mathrm{R}$, Thompson MF (eds) Fouling organisms of the Indian Ocean: biology and control technology. AA Balkema, Rotterdam, p 31-83

Walters LJ, Hadfield MG, Smith CM (1996) Waterborne chemical compounds in tropical macroalgae: positive and negative cues for larval settlement. Mar Biol 126:383-393

Wieczorek SK, Todd CD (1998) Biofilm cues and larval settlement. Biofouling 12:81-118

Zar JH (1996) Biostatistical analysis, 3rd edn. Prentice-Hall, Upper Saddle River, NJ

Submitted: July 30, 2003; Accepted: March 2, 2004

Proofs received from author(s): June 2, 2004 